\title{
Evaluation of the changes on hemostatic parameters induced by valdecoxib in male Wistar rats
}

\author{
Avaliação dos efeitos do valdecoxibe sobre os parâmetros hemostáticos de ratos Wistar
}

\author{
Marcio Fronza ${ }^{1}$ \\ Micheli Wrasse ${ }^{2}$ \\ Liberato Brum Junior ${ }^{1}$ \\ Maximiliano S. Sangoi ${ }^{2}$ \\ Sérgio L. Dalmora ${ }^{3}$
}

\begin{abstract}
The effects of the cyclooxygenase (COX)-2 selective inhibitor, valdecoxib, on blood coagulation parameters were evaluated, along with aspirin in male Wistar rats. Groups of animals were administered a daily oral dose of $10 \mathrm{mg} / \mathrm{kg}$ rat of valdecoxib, 100 $\mathrm{mg} / \mathrm{kg}$ rat of aspirin and the vehicle alone during 4 weeks. Blood samples were collected at the end of 1, 2, 3 and 4 weeks of administration period and the plasma concentrations of valdecoxib were determined by RP-HPLC giving mean values of 101.1, 113.5, 164.0 and $184.6 \mathrm{ng} / \mathrm{mL}$, respectively. The same plasma samples were used for the analysis of hematological parameters and the results compared to the controls. Valdecoxib induced significant activated partial thromboplastin time reduction (18\%) after 2 weeks and prothrombin time reduction (12.2\%) after 3 weeks $(P<0.05)$. There were no significant changes in the platelet count and fibrinogen levels. The antifactor Xa and anti-factor IIa activities showed slight reductions, but only significant for the anti-factor Xa on the 3rd week (6.7\%). The results showed that valdecoxib at the dose tested with the plasmatic concentrations induced some changes in the hemostatic function of rats, which can be helpful to understand the side effects and the safe use of the drug. Rev. bras. hematol. hemoter. 2006;28(1):28-32.
\end{abstract}

Key words: Valdecoxib; coagulation; liquid chromatography; rats; factor Xa.

\section{Introduction}

Hemostasis involves a complex system of factors that work within a delicate balance allowing the body to control the loss of blood while protecting against tissue ischemia, necrosis and resultant myocardial infarctions due to blood clotting in a vessel. ${ }^{1}$

Cyclooxygenase- 2 selective inhibitors have been marketed since 1999 as alternatives to traditional nonsteroidal anti-inflammatory drugs (NSAIDs). The COX enzyme exists in two isoforms, a constitutive isoform (COX-1) mainly associated with homeostasis, and an inducible isoform (COX-2) which is associated with inflammation and is selectively inhibited by the NSAID valdecoxib, described chemically as 4-(5-methyl-3phenylisoxazol-4-yl) benzenesulfonamide., ${ }^{2,3}$

The expression of COX-2 in the vascular endothelium has been suggested to explain why the use of a high dose and chronic administration of valdecoxib has been in some, but not all studies, associated with increased risk for cardiac events. The current hypothesis is that while selective COX2 inhibition does not affect the proaggregatory and vasoconstricting effect of thromboxane A2 (TXA2) produced by thrombocytes, it may significantly block the COX-2 dependent production of endothelial prostacyclin (PGI2) resulting in an imbalance of the aggregatory system in fa-

\footnotetext{
${ }^{1}$ Industrial Pharmacy, Master in pharmaceutical Sciences.

${ }^{2}$ Industrial Pharmacy.

Correspondência para: Sérgio Luiz Dalmora

Departamento de Farmácia Industrial - Campus UFSM

97105-900 - Santa Maria-RS - Brasil

Tel.: (+55) 3220-8805 -

E-mail: sdalmora@ccs.ufsm.br
}

${ }^{3}$ Professor of the Industrial Pharmacy Department, Doctor in Biological Sciences, Unifesp.

Departamento de Farmácia Industrial, Centro de Ciências da Saúde,Universidade Federal de Santa Maria - Santa Maria-RS - Brazil. 
vor of thrombus formation and vasoconstriction. ${ }^{4-7}$ This balance of TXA2/PGI2 is crucial to maintain hemostasis of coagulation pathways that can be evaluated by the clinical laboratory assays.

Moreover, due to the recent findings, safety monitoring and additional studies will be essential to understand the mechanisms and evaluate safe dosage levels of coxibs as anti-inflammatory and also as a potential new candidate in the prevention and treatment of cancer. ${ }^{8,9}$

The aim of the present study was to determine the plasma concentration achieved by oral administration of a selected dose of valdecoxib, investigate the effects on different blood coagulation parameters during the administration time of four weeks, and compare the results to those obtained by using aspirin.

\section{Materials and Methods}

\section{Materials}

The valdecoxib reference standard was generously supplied by Pfizer Laboratories (Kalamazoo, USA). Valdecoxib active pharmaceutical ingredient was obtained from Ultratech India Ltd (New Bombay, India). Aspirin was purchased from Sigma (St. Louis, USA). Ezetimibe (internal standard, I.S.) was obtained from Sequoia Research products (Oxford, United Kingdom). Factor Xa from bovine plasma was purchased as "DIAGEN" from Diagnostic Reagents Ltd (Thame, UK) and factor IIa from human plasma was purchased from Sigma (St. Louis, USA). Chromogenic substrates S-2765 and S-2238 were from Chromogenix (Milan, Italy). All other chemicals and reagents used were of the highest purity and were purchased from Tedia (Fairfield, USA) and Merck (Darmstadt, Germany).

\section{Animals and test samples}

Experimental animal studies were conducted in accordance with the national protection laws on animal welfare. Male wistar rats were housed under controlled conditions. Room temperature was kept constant $\left(20-22^{\circ} \mathrm{C}\right)$ with 12:12 h, light-dark cycles and food and water ad libitum during the trial. A total of seventy-two animals were distributed in a fully randomized order and divided by color code into valdecoxib, aspirin and control groups with usually six rats for each treatment group. The assays were carried out with animals with a body weight that ranged from 180 to $200 \mathrm{~g}$. Valdecoxib and aspirin were administered once a day orally by gavage ( $10 \mathrm{mg} / \mathrm{kg}$ and $100 \mathrm{mg} / \mathrm{kg}$, respectively) as a suspension in $0.5 \%$ aqueous carboxymethylcellulose and control animals received the vehicle.

\section{Methods}

\section{Blood collection}

The blood collection was carried out on the 1st, 2nd, 3rd, and 4th weeks following continuous daily oral administration of the respective doses. After anesthetizing the rats intraperitoneally with sodium pentobarbitone (40 mg/kg), approximately $5.5 \mathrm{~mL}$ of blood was collected from the abdominal aorta using disposable polypropylene syringes and $0.5 \mathrm{~mL}$ was transferred to a disposable tube containing $0.05 \mathrm{~mL}$ of EDTA, for platelet count. The remaining blood was immediately transferred to a plastic tube containing 3.8\% sodium citrate solution to give the anticoagulant-blood ratio 1:10. The blood was mixed gently and centrifuged at $900 \times \mathrm{g}$ for 15 minutes at $4^{\circ} \mathrm{C}$. This citrated plasma was used for the determination of valdecoxib concentration and coagulation studies (prothrombin time PT, activated partial thromboplastin time - APTT, fibrinogen level and anti-factor Xa and anti-factor IIa activities).

\section{Platelet counting}

The platelet counting was performed by the fluorescence method using an automated flow cytometer (ABX Diagnostics, Montpellier, France).

\section{Coagulation parameters}

The coagulation tests, prothrombin time (PT) and fibrinogen level were measured in duplicate by the photometric method using an automated coagulation analyzer (Sysmex, Kobe, Japan). The activated partial thromboplastin time (APTT) assay was performed in triplicate. A total of $100 \mu \mathrm{L}$ of sodium chloride solution (9 g/L) and $100 \mu \mathrm{L}$ of thawed plasma sample was transferred to respective tubes in the coagulometer at $37^{\circ} \mathrm{C}$, and allowed to equilibrate for 5 minutes. Then, $100 \mu \mathrm{L}$ of a mixture of equal volumes of kaolin (4 $\mu \mathrm{g} / \mathrm{mL})$ and phospholipid (49.4 $\mu \mathrm{g} / \mathrm{mL}$ ) was added. After exactly two minutes, $100 \mu \mathrm{L}$ of calcium chloride solution ( $25 \mathrm{mmol} / \mathrm{L}$ ) was added and the clotting time recorded for each tube. ${ }^{10}$

\section{Anti-factor Xa and anti-factor IIa assays}

The assays were carried out in triplicate by the method described with small modifications. ${ }^{11}$ For anti-factor Xa assay, a total of $25 \mu \mathrm{L}$ of plasma was transferred to a well of a 96-well plate and then allowed to equilibrate at $37^{\circ} \mathrm{C}$ (water bath or heating block) before adding $50 \mu \mathrm{L}$ of bovine factor Xa solution. The plate was incubated for exactly two min and then $100 \mu \mathrm{L}$ of chromogenic substrate S-2765 was added. The reaction was stopped after exactly four min by adding $100 \mu \mathrm{L}$ of $20 \%$ acetic acid. The absorbance was measured at $405 \mathrm{~nm}$ in a microplate reader. The assay was performed in triplicate.

Anti-factor IIa assay was carried out changing the procedure described above for the anti-factor Xa assay by using bovine factor IIa solution and the chromogenic substrate S-2238.

Determination of valdecoxib concentration An isocratic high-performance liquid chromatography 
procedure was used for quantitative estimation of valdecoxib in plasma. Valdecoxib and ezetimibe (internal standard) were extracted from plasma by liquid-liquid extraction using tertbutil methyl ether extraction solvent and carried out on a reversed phase Phenomenex (Torrance, USA) Synergi fusion $\mathrm{C}_{18}$ column (150 mm x $4.6 \mathrm{~mm}$ I.D., with a particle size of $4 \mu \mathrm{m}$ and pore size of $80 \AA$ ). A security guard holder (4.0 $\mathrm{mm} \times 3.0 \mathrm{~mm}$ I.D.) was used to protect the analytical column. The HPLC system was operated isocratically and the column was operated at $40^{\circ} \mathrm{C}$ using a mobile phase of water, $\mathrm{pH} 7.0$ adjusted with $\mathrm{NaOH} 0.1 \mathrm{M}$ /acetonitrile $(51: 49, \mathrm{v} / \mathrm{v})$. This was filtered through a $0.45 \mu \mathrm{m}$ membrane filter (Millipore) and run at a flow rate of $1.0 \mathrm{~mL} / \mathrm{min}$ and with $\mathrm{UV}$ detection at $210 \mathrm{~nm}$.

\section{Statistical analysis}

Data are expressed as means \pm S.E.M. Significant differences between the test and control groups were determined by the student's t-test, at a level of $P<$ 0.05. (SAS 6.1 for Windows, SAS Institute Inc., USA).

\section{Results and Discussion}

The experiment was carried out using the doses selected as, approximately, eight times higher than the human clinical dose (adjusted to the body weight), for valdecoxib, and three times higher for aspirin. ${ }^{12,13}$ The assay design was established for the evaluations as subacute biological effects during one month. The blood samples were collected and the plasma concentrations of valdecoxib measured by reverse-phase liquid chromatography (RP-HPLC), as shown in Table 1.

The mean platelet count was $729 \pm 94 \times 10^{3}$ and 704 $\pm 81 \times 10^{3} \mathrm{~mm}^{3}$ for valdecoxib and aspirin, respectively. Comparing the results to the controls and also to each other,

Table 1

RP-HPLC determination of plasma concentrations $(\mathrm{ng} / \mathrm{mL})$ of valdecoxib following daily oral administration of $10 \mathrm{mg} / \mathrm{kg}$ rat in male rats

\begin{tabular}{cccccc}
\hline \multirow{2}{*}{ Animals } & \multicolumn{5}{c}{$\begin{array}{c}\text { Concentration }(\mathrm{ng} / \mathrm{mL}) \\
\text { Time (weeks) }\end{array}$} \\
& 0 & 1 & 2 & 3 & 4 \\
\hline 1 & nd $^{\mathrm{a}}$ & 110.6 & 110.2 & 153.2 & 183.1 \\
2 & $\mathrm{nd}$ & 87.8 & 125.1 & 147.9 & 190.2 \\
3 & $\mathrm{nd}$ & 105.3 & 109.8 & 180.2 & 175.3 \\
4 & $\mathrm{nd}$ & 95.7 & 98.3 & 165.7 & 160.4 \\
5 & $\mathrm{nd}$ & 108.4 & 122.6 & 172.3 & 210.1 \\
6 & $\mathrm{nd}$ & 98.9 & 114.7 & 164.8 & 188.7 \\
Mean & - & 101.1 & 113.5 & 164.0 & 184.6 \\
CV (\%) & - & 8.5 & 8.6 & 7.3 & 9.0 \\
\hline
\end{tabular}

${ }^{a}$ nd, not detected non-significant differences were observed at all administration times, demonstrating that valdecoxib does not affect this hematological parameter.

The mean of the fibrinogen level was $198 \pm 21$ and $201 \pm 35 \mathrm{mg} / \mathrm{dL}$ for valdecoxib and aspirin, respectively. There was no significant effect of valdecoxib and aspirin on fibrinogen level at any time of the experiment.

The blood clotting process is complex, involving many factors found in the plasma and tissues. Substances that affect the PT are thought to act on the extrinsic pathway factors: factors V, VII, X, prothrombin and fibrinogen, while those that affect the APTT act on the components of the intrinsic pathway, that is, all coagulation factors except factors VII and XIII. ${ }^{14}$ The effects of valdecoxib and aspirin on PT are shown in Table 2. A significant reduction (12.2\%) was observed only with the group that received valdecoxib during three weeks $(P<0.05)$. Administration of the same dose for four weeks caused a PT prolongation (by 3.7\%), when

Table 2

Effect of administration of valdecoxib and aspirin for 1, 2, 3 and 4 weeks on prothrombin time $(\mathrm{PT})$ of male rats

\begin{tabular}{ccccc}
\hline \multirow{2}{*}{ Animal Group } & \multicolumn{4}{c}{ Prothrombin time in seconds (mean \pm S.E.M.)* } \\
\cline { 2 - 5 } & 1 week & 2 weeks & 3 weeks & 4 weeks \\
\hline Control & $11.1 \pm 0.07$ & $10.9 \pm 0.13$ & $10.6 \pm 0.07$ & $10.8 \pm 0.35$ \\
Aspirin & $11.2 \pm 0.43$ & $11.1 \pm 0.30$ & $11.0 \pm 0.45$ & $11.3 \pm 0.62$ \\
Valdecoxib & $11.2 \pm 0.31$ & $10.8 \pm 0.47$ & $9.3 \pm 0.33^{\star \star}$ & $11.2 \pm 0.15$ \\
\hline
\end{tabular}

* six rats per group

** Student's t-test, significantly different from control $\mathrm{P}<0.05$

compared to that of the control, but the difference was not statistically significant. The group receiving aspirin showed prolongation of the PT compared to that of the control, during all the experiment, although changes were not significant.

The APTT assay showed that there was a significant shortening of the APTT results (by 18\%) after administration for two weeks, compared to the controls $(P$ $<0.05$ ) (Table 3). Aspirin produced an increase of APTT during all the experiment, but these data were not statistically significant.

The effects of valdecoxib and aspirin on factor Xa and factor IIa of the coagulation cascade are shown in Figure 1. For the anti-factor Xa a reduction of 3.1, 2.2 and 6.7\% was observed after 1, 2 and 3 weeks, respectively, but the difference was significant only in the 3rd week $(\mathrm{P}<0.05)$. This shortening of anti-Xa activity (units/mL) indicated that the use of valdecoxib can cause some coagulant effect, probably due to the decrease of natural inhibitors of coagulation like antithrombin, protein $\mathrm{C}$, protein $\mathrm{S}$ or tissue factor pathway inhibitor. Furthermore for all the experiment, aspirin showed an increase of anti-Xa activity of 3.0, 6.5, 
Table 3

Effect of administration of valdecoxib and aspirin for 1, 2, 3 and 4 weeks on activated partial thromboplastin time (APTT) of male rats

Activated partial thromboplastin time, in seconds (mean \pm S.E.M.)*

\begin{tabular}{ccccc} 
Animal Group & \multicolumn{4}{c}{ in seconds $($ mean \pm S.E.M.) } \\
& 1 week & 2 weeks & 3 weeks & 4 weeks \\
\hline Control & $39.2 \pm 1.61$ & $41.5 \pm 1.30$ & $41.3 \pm 1.15$ & $44.3 \pm 1.17$ \\
Aspirin & $39.4 \pm 0.90$ & $44.3 \pm 1.26$ & $42.3 \pm 0.71$ & $48.1 \pm 1.51$ \\
Valdecoxib & $38.2 \pm 0.58$ & $34.0 \pm 0.62^{\star *}$ & $39.9 \pm 0.85$ & $48.2 \pm 1.18$
\end{tabular}

* Six rats/group

** Student's t-test, significantly different from controls $\mathrm{P}<0.05$

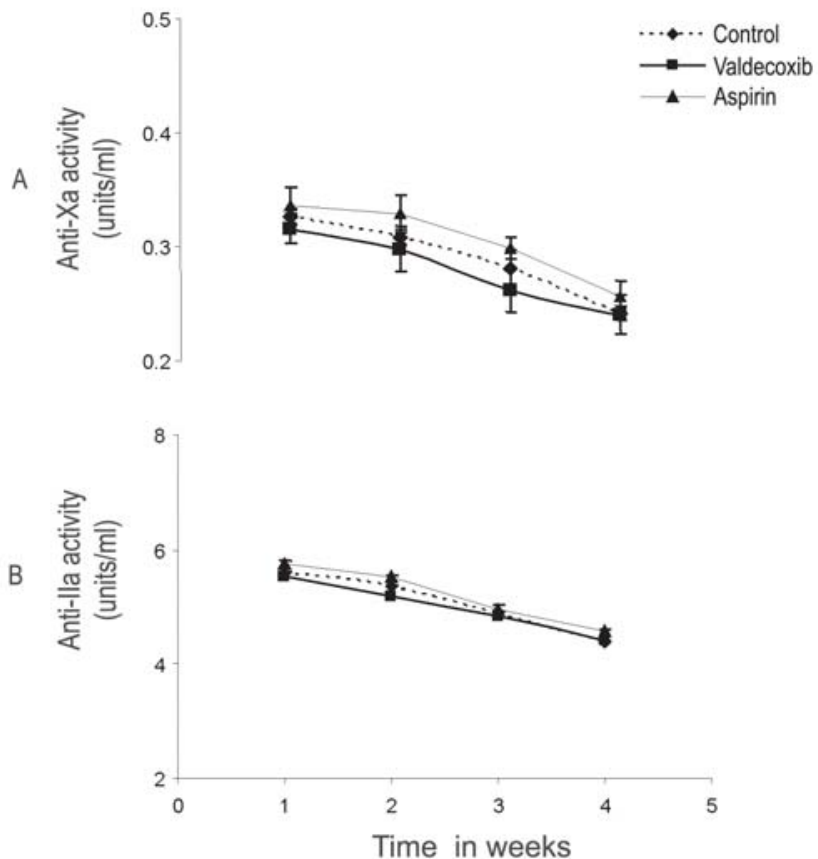

Figure 1. Anti-factor Xa activity (A) and anti-factor Ila activity (B) evaluated in plasma after daily oral administration of $10 \mathrm{mg} / \mathrm{kg}$ rat of valdecoxib and $100 \mathrm{mg} / \mathrm{kg}$ rat of aspirin, respectively, at 1, 2, 3 and 4 weeks. Groups of six rats and the data expressed as mean \pm S.D

6.3 and 5.9\%, compared to the controls, but despite of being non-significant $(\mathrm{P}>0.05)$, it is confirming the known antiaggregating effect of the drug.

In parallel, when evaluating the anti-factor IIa activity of valdecoxib, a slight non-significant reduction was found calculated at 1.1 and $3.1 \%$ for the 1 st and 2nd week, respectively. For the following two weeks there were no changes. Besides, aspirin showed an increase of the anti-IIa activity of 3.2, 3.5, 1.9 and $4 \%$, that was non-significant.

Coagulation consists of a series of zymogens that can be converted by limited proteolysis to active enzymes leading to the generation of thrombin, which in turn converts fibrinogen into fibrin. Based on the present evidence, valdecoxib may be related to the initiation of coagulation cascade and thrombus formation that could be helpful to understand cardiovascular complications, such as myocardial infarction reported with valdecoxib. ${ }^{4}$ This idea is supported by our data showing that significant reduction was found for APTT, PT and anti-factor Xa.

\section{Conclusion}

On the basis of the present findings, using daily oral administration at a selected dose, eight times higher than that intended for human therapeutic use, during one-month, valdecoxib seems to produce some changes in the blood coagulation parameters, with emphasis on APTT, PT and factor Xa. The results are important to understand the side effects and for the safe use of valdecoxib for inflammatory diseases or the prevention and treatment of cancer, leading to comparisons of more established drugs of the respective pharmacological group.

\section{Resumo}

Avaliaram-se os efeitos do valdecoxibe, um inibidor seletivo da cicloxigenase-2 (COX-2), sobre os parâmetros sangüíneos da coagulação em ratos Wistar utilizando-se paralelamente a aspirina. Os animais foram divididos em grupos e submetidos à administração oral diária de $10 \mathrm{mg} / \mathrm{kg}$ animal para o valdecoxib, 100 $\mathrm{mg} / \mathrm{kg}$ animal para a aspirina e veículo para o grupo controle, durante quatro semanas. A coleta do sangue foi efetuada após uma, duas, três e quatro semanas, e as concentrações plasmáticas do valdecoxibe determinadas por cromatografia líquida, obtendo-se valores médios de 101,1 - 113,5 - 164 e 184,6 ng/ml, respectivamente. As amostras de plasma foram também usadas para as análises hematológicas e os resultados comparados aos dos controles. O valdecoxibe apresentou redução significativa no TTPA (18\%) após duas semanas, e redução do TP (12,2\%) após três semanas $(P<0.05)$. Os efeitos observados na contagem de plaquetas e nos níveis plasmáticos de fibrinogênio não foram significativos. As atividades anti-fator Xa e anti-fator IIa apresentaram redução, porém os resultados foram significativos somente para o anti-fator Xa na terceira semana (6,7\%). Os resultados experimentais com as concentrações plasmáticas alcançadas demonstram que o valdecoxibe pode induzir alterações nos parâmetros hematológicos dos ratos. Esses dados poderão contribuir para a melhor compreensão dos efeitos colaterais e uso do fármaco com segurança. Rev. bras. hematol. hemoter. 2006;28(1):28-32.

Palavras-chave: Valdecoxibe; coagulação; cromatografia líquida; ratos; fator Xa.

\section{Acknowledgements}

The authors wish to thank Capes and Fapergs for their support. 


\section{References}

1. Stassen JM, Nystrom A. A historical review of hemostasis, thrombosis, and antithrombotic therapy. Ann Plast Surg 1997;39:317-29.

2. Talley JJ, Brown DL, Carter JS et al. 4-[5-Methyl-3-phenylisoxazol-4yl]-benzenesulfonamide, Valdecoxib: A potent and selective inhibitor of COX-2. J Med Chem 2000;43:775-7.

3. Catella-Lawson F, Crofford LJ. Cyclooxygenase Inhibition and Thrombogenicity. Am J Med 2001;110:28-32.

4. Fitzgerald GA. Coxibs and cardiovascular disease. N Engl J Med 2004; 351:1709-11.

5. Topol EJ. Arthritis Medicines and Cardiovascular Events - "House of Coxibs". JAMA 2005; 293:366-8.

6. Howard PA, Delafontaine P. Nonsteroidal anti-inflammatory drugs and cardiovascular risk. J Am Coll Cardiol 2004;43:519-25.

7. Bennett JS, Daugherty A, Herrington D et al. The use of nonsteroidal anti-inflammatory drugs (NSAIDs). Circulation 2005;111:1.713-16.

8. Konstantinopoulos PA, Lehmann DF. The cardiovascular toxicity of selective and nonselective cyclooxygenase inhibitors: Comparisons, contrasts, and aspirin confounding. J Clin Pharmacol 2005;45:742-50.

9. Hull MA. Cyclooxygenase-2: How good is it as a target for cancer chemoprevention? Eur J Cancer 2005; In press.

10. Vaccari SF, Brum Junior L, Masiero SMK et al. Avaliação comparativa da atividade de heparinas não-fracionadas em produtos farmacêuticos. Rev Bras Hematol Hemoter 2003;25:103-10.

11. Dalmora SL, Brum Junior L, Fronza M et al. Validation of the anti-factor IIa assay and potency assessment of enoxaparin in pharmaceutical formulations. Il Farmaco 2005; 60:225-9.

12. Doutremepuich F, Aguejouf O, Imbault P et al. Effect of the low molecular weight heparin/non steroidal anti-inflammatory drugs association on an experimental thrombosis induced by laser. Thromb Res 1995;77:311-9.

13. Product Information: Bextra ${ }^{\circledR}$, Valdecoxib. Pharmacia Corporation, Chicago, Il, (PI developed 11/2001) reviewed 11/2001.

14. O'Shaughnessy D, Makris M, Lillicrap D. Practical Hemostasis and Thrombosis. Oxford, United Kingdom: Blackwell Publishing 2005, 224p.

Avaliação: Editor e dois revisores externos.

Conflito de interesse: Pfizer Laboratories supplied the valdecoxib

Recebido: 10/08/2005

Aceito após modificações: 16/01/2006

Recursos financeiros: Capes and Fapergs 